5. Nietzsche, F. (2003). Birth of the Tragedy. Nietzsche F. Thus spoke Zarathustra. To the genealogy of morality. Birth of tragedy. Will to power. Posthumous aphorisms: transl. from Germ. F. Nietzsche (Ed). Minsk: Harvest [in Russian].

6. Plai. (1996). The book for reading about Hutsulshchyna. I. Pelypeiko (ed, aut. of notes, references and vocab). Yavoriv: Editorial Board of the «Hutsul School» magazine [in Ukrainian].

7. Senyukov, I. (1995). Hutsul heritage. Works on Hutsuls' life and art. Kyiv: Ukrainian Studies [in Ukrainian].

Ukrainian].

8. Fedkovich, O. Yu. (1906) It serves your right! Fedkovich O. Yu. Writing. T.III, Part 1a: Drama. Lviv [in

9. Hotkevich, G. (1997) «The Shadows of Forgotten Ancestors»: Ukrainian Language and Literature. Number 47 (63) [in Ukrainian].

10. Hotkevich, G. M. (2010) Dovbush: Tale. Kharkiv: Folio [in Ukrainian].

11. Tsybinden, G. (1993) Traveling on the Hutsul Mountains. Travel to Ukrainian Carpathians: Collection. M. Valio (ed). Lviv: Kamenyar [in Ukrainian].

12. Shukhevich, V. (1899) Hutsulshchyna. Materials to the Ukrainian-Russian ethnology. Lviv [in Ukrainian].

13. Hacquet's neueste physikalisch-politische Reisen in den Jahren 1791 - 92, und 93 durch die Dacischen und Sarmatischen oder Nördlichen Karpathen (1794). Nürnberg. [in German].

14. J.F.H. (Hołovacki) (1841). Cesta po Halické a Uherské Rusi: Sdelena v listech od J.F.H. ku přjteli do L. Časopis Českého Museum. Praga [in Czech].

15. Wahylewiĉ, D.J. (1839). Huculowé, obywatelé wýchodnjho pohořj Karpatského. Časopis Českého Museum. Praga [in Czech].

16. Wójcicki, K.W. (1842). Zarysy domowe. Warshawa [in Polish].

Стаття надійшла до редакції 11.07.2018 p.

UDC 37.02:004

Karpenko Oleksandr
PhD (Public Administration),
Chairman of Information Policy
and Digital Technologies Faculty,
National Academy of Public Administration,
under the President of Ukraine
ORCID 0000-0002-9301-7973
dr.karpenko@ukr.net;
Zaporozhets Tetiana
Cand. Sc. (Public administration),
Candidate for a Doctor's Degree of Information
Policy and Digital Technologies Faculty,
National Academy of Public Administration,
under the President of Ukraine
ORCID 0000-0003-1914-9481
ztv2016@ukr.net

\title{
SYNERGY OF TECHNOLOGIES AND CULTURE UNDER CONSDITIONS OF THE DEVELOPMENT OF DIGITAL SOCIETY
}

The purpose of the research is to analysis the synergistic interaction of culture and modern innovative technologies in various scientific fields and determine their impact on the development of digital society. Research Methodology. The study used general scientific methods of comparison, statistical analysis of factors and phenomena, inductive and deductive methods, analysis and synthesis. Scientific novelty consists in substantiating the synergetic tendencies of modern innovative technologies and culture, which leads to a change in our understanding of the world and essence of natural processes and phenomena and the creation of a basis for transferring a qualitatively new state of human capabilities through technological innovations. Conclusions. As a result of the study, close relationship between modern technologies and culture has been established, and their influence on the development of modern digital society has been substantiated.

Key words: modern innovative technologies; artificial intelligence; digital culture; digital society.

Карпенко Олександр Валентинович, доктор наук з державного управління, завідувач кафредри інфрормаційної політики та цифрових технологій Національної академії державного управління при Президентові України; Запорожець Тетяна Володимирівна, кандидат наук з державного управління, докторант кафедри інформаційної політики та цифрових технологій Національної академії державного управління при Президентові України.

Синергія технологій та культури в умовах розвитку цифрового суспільства

Метою роботи є здійснення аналізу синергетичної взаємодії культури та сучасних інноваційних технологій в різних наукових сфрерах та визначення їх впливу на розвиток цифрового суспільства. Методологія дослі-

(C) Karpenko O., 2018

(c) Zaporozhets T., 2018 
дження. У дослідженні використано загальнонаукові методи порівняння, статистичного аналізу факторів та явищ, індуктивний та дедуктивний, аналізу та синтезу. Наукова новизна полягає в доведенні синергетичних тенденцій сучасних інноваційних технологій та культури, що призводить до зміни наших уявлень про світ та сутність природних процесів та явищ та створення основи для переведення у якісно новий стан рівня людських можливостей завдяки технологічним новаціям. Висновки. В результаті дослідження з'ясовано тісний взаємозв'язок сучасних технологій та культури, обґрунтовано їх вплив на розвиток сучасного цифрового суспільства.

Ключові слова: сучасні інноваційні технології; штучний інтелект; цифрова культура; цифрове суспільст-

Bo.

Карпенко Александр Валентинович, доктор наук государственного управления, заведующий кафредрой информационной политики и цифровых технологий Национальной академии государственного управления при Президенте Украины; Запорожец Татьяна Владимировна, кандидат наук государственного управления, докторант кафредры информационной политики и цифровых технологий Национальной академии государственного управления при Президенте Украины.

Синергия технологий и культуры в условиях развития цифрового общества

Целью работы является осуществление анализа синергетического взаимодействия культуры и современных инновационных технологий в различных научных сферах и определение их влияния на развитие цифрового общества. Методология исследования. В исследовании использованы общенаучные методы сравнения, статистического анализа факторов и явлений, индуктивный и дедуктивный методы, анализа и синтеза. Научная новизна заключается в обосновании синергетических тенденций современных инновационных технологий и культуры, что приводит к изменению наших представлений о мире и сущности природных процессов и явлений и созданию основы для перевода в качественно новое состояние уровня человеческих возможностей благодаря технологическим новациям. Выводы. В результате исследования установлена тесная взаимосвязь современных технологий и культуры, обосновано их влияние на развитие современного цифрового общества.

Ключевые слова: современные инновационные технологии; искусственный интеллект; цифровая культура; цифровое общество.

Introduction. The process of introducing intellectual management and digitalisation of managerial processes today touches practically all countries of the world. Advanced countries are changing the paradigm of their own national economies, giving preference to the latest developments and technologies. Obviously, these changes are due to the introduction of many technological innovations that are used in various industries. At the same time, the interconnection of modern digital technologies and culture leads to the creation of a basis for the transition to a qualitatively new level of human capabilities, as well as to change of our perceptions of the world and the nature of natural processes and phenomena, and thus contributes to the development of a new digital society.

The purpose of the work is to analyze the synergetic interaction of culture and modern innovative technologies in various scientific fields and determine their impact on the development of digital society.

Statement of basic materials. At the present stage, so-called breakthrough innovative technologies are commonly used to denote the abbreviation NBIC - (Nano; Bio; Info; Cogno) technology.

The term NBIC technology was introduced in 2002 by the American scientist of Romanian origin, M.K Roco (founder of the subcommittee of the National Science and Technology Council of the US for nanoscale science, technology (NSET), Senior Advisor on Science and Technology of the National Science Foundation) in the scientific The workshop "Combining Techniques for Improving Human Productivity", prepared by the World Technology Assessment Center (WTAC) [1].

As noted by M.K Roco, the NBIC-technology's characteristic feature is the intensive interaction between scientific and technological spheres, the broad applicability (from the atomic level of matter to the intellectual systems), as well as the technological perspective of the growth of human development opportunities. Modern NBIC-technologies allow for the qualitative growth of technological capabilities of individual and social personality development [1].

The research interest in the issues of the interconnection of technologies and culture is due to the rapid development of modern scientific and technological achievements, which create and form a fundamentally new digital society. They provide an opportunity to quickly solve the problems of information hunger and enter a new level of interpersonal communication, which, in the conditions of globalization, becomes intercultural and interreligious. In such a society there are new transformations in various processes of human life.

The information revolution, which is the result of scientific and technological progress in recent years, has led to an increase in the role of information and knowledge and, as a consequence, a new level of development of modern society. Its main driving force is the information and knowledge that are an important factor in production. In this regard, the scientists call the modern society "informational" (O. Toffler, J. Masuda, D. Bell) [2; 3; 4], or "a knowledge-based society" (P. Draker) [5], or based on the "information economy" or "knowledge economy" (M. Porat) [6].

Through the development of the system of continuous education, as well as national, regional and local systems of innovation (M. Porter) [7], we observe the achievements of modern society in many spheres.

For example, in an industrial context, the approach to work changes, and new professional competencies are determined, which require a creative and intellectual contribution of a person. At the present 
stage, society lives in a so-called accelerated "inflation of qualifications", when the competences that are needed at present can lose their value in the future, because there will be a need for completely new ones.

Gradually changing the key concepts related to employment (labor biography, employment contract, place of work, working time), the following new categories come: mobile workplace, flexible schedule, virtual office. There are new forms of interaction between the subjects of the labor market - flexible (unstable) forms of employment.

The place and role of man in a modern organization is changing. This is not an executor, but an object and subject of management. A new paradigm of intellectual governance (intellectual management) is emerging, according to which the success of any organization will depend on the joint application of human intelligence and artificial intelligence.

The widespread introduction to the management and production processes of digital technologies has become the cause of the emergence of new management models that operate in the context of global network interactions. These models are characterized by extraterritoriality, universality, interactivity, which is based on the integration of human capabilities and artificial intelligence [8].

In this regard, it will be appropriate to focus on the work of the European Commission, which is extremely active in the development and dissemination of digital technologies in the world. The European Commission defines the digital economy as an environment that allows each company or individual to quickly and inexpensively communicate with another company or person for trading, sharing ideas and knowledge, collaborating, etc.

One of the priority areas of the commission's activities is the "Digital Single Market" strategy, as a set of mechanisms for ensuring the active participation of each citizen in the development of the digital society.

Implementing the "Digital Single Market" strategy, the commission adopted a series of initiatives and legislative proposals on September 14, 2016. In particular, it is planned that by 2025 all schools, transport nodes and major providers of public services, as well as digital rights companies, should have access to Internet connections at $1 \mathrm{~GB} / \mathrm{s}$ upload / unloading speed.

In addition, all European households, rural and urban, will have access to networks with a download speed of at least $100 \mathrm{Mbp} / \mathrm{s}$ and should be upgraded to $1 \mathrm{Gbit}$, and all urban areas as well as major roads and railways should have uninterrupted broadband wireless connectivity $5 \mathrm{G}$. Thus, according to scientists, these and other measures should ensure the competent participation of a citizen in the processes of the formation of modern digital society [9].

In the context of research on the analysis of the synergistic interaction of modern innovative technologies and culture in the context of the development of a digital society, one should mention Elvin Toffler, an American philosopher, sociologist and futurologist, one of the authors of the concept of postindustrial society, who emphasized that the scale of the transition from industrial society to postmodernism goes far beyond technical and information innovations. He noted that the awareness of the formation of a new culture will take place at an ever-increasing pace. This is due not only to the impact of total computerization and globalization, but also the emergence of new settings regarding the attitude to work, employment, sex, leisure, etc [2].

Summarizing, in the end, we should talk about creating a basis for translating into a qualitatively new condition the level of human capabilities and the development of modern digital culture, due to radical technological restructuring, as well as change our perceptions about the world and the nature of natural processes and phenomena.

All of the foregoing proves that the rapid development of digital technologies accelerates the process of transformation of the technological structure, rapidly develops society and man, and also indicates a rapid progress in the study of the laws of the existence of social structures, because the growing autonomy of individuals will inevitably lead to the emergence of new communities, social norms and ethical criterias.

As noted in previous publications, digital culture today is becoming a factor affecting social and professional mobility and as a result significantly changes the model of behavior of the modern generation. Under the influence of the development of digital technologies transformed traditional cultural areas, which leads to a change in the social outlook and revaluation of values. The meaning of the term "digital culture" may have a different semantic load, but in the context of professional activity, this refers to the ability of a person to apply his digital knowledge, skills and competencies; in the context of everyday communication this is a harmonious combination of the digital world and classical approaches to understanding the culture of behavior [10, c. 51].

Conclusions. Thus, the development of modern innovative technologies in their relationship with the development of culture can be the beginning of a new phase of human evolution - a stage of directed conscious social evolution, which consists in the presence of the goal, in contrast to the evolutionary process based on the mechanisms of natural selection.

Man is still a measure of all things, with the only difference that it is becoming more difficult to define the limits of the human being, since the technical exists not only outside the person, but also in it itself, in the form of artificial tissues, organs, medicines, and the like. In addition, modern education, upbringing, and the formation of the outlook also takes place with the direct participation of innovative technologies [11, c. 317]. 
It should take into account the prospects for solving not only the actual technological problems, but also a wide range of ethical, social and philosophical and anthropological problems directly related to them, from the assessment of the possibility of creating in the near future self-reproducing artificial intelligence built on the basis of nanoscale, to comprehension of whether the theoretical basis for the distinction between natural and artificial in humans and the environment will be preserved. Consequently, the prospects for the development of science and technology give reason to believe that in the future a radical transformation of people is possible not only of the material world, but also of subjective reality.

\section{תimepamypa}

1. Roco M.C. Coherence and Divergence of Megatrends in Science and Engineering / Converging Technologies for Improving Human Performance NANOTECHNOLOGY, BIOTECHNOLOGY, INFORMATION TECHNOLOGY AND COGNITIVE SCIENCE. - NSF/DOC-sponsored report. Dordrecht: Kluwer Academic Publishers, 2003. 482 p. URL: https://www.wtec.org/ConvergingTechnologies/Report/NBIC_report.pdf

2. Alvin Toffler. Creating a New Civilization: The Politics of the Third Wave. Front Cover. /Alvin Toffler, Heidi Toffler/ Turner Pub., 1995 - Business \& Economics. 112 p.

3. Bell D. The Coming of Post-Industrial Society: A Venture in Social Forcasting. N.Y.: Basic books, 1973.

4. Masuda Y. The Information Society as Postindustrial Society. Wash.: World future soc. Wings to Human Ability / Government Commission on Information Technology. Sweden: Prime Minister's Office. 1994.

5. P. Drucker. Innovation and Entrepreneurship., 1985. 250 p.

6. M. Porat. The Information Economy: Development and Measurement. Wash., 1978. 274 p.

7. Porter M. E., Kramer M. R. Strategy and Society: The Link Between Competitive Advantage and Corporate Social Responsibility // Harvard Business Review, December 2006, p. 78-92.

8. About Improving connectivity and access. URL: https://ec.europa.eu/info/research-and-innovation_en

9. The European Commission. Official web-site. URL: https://ec.europa.eu/digital-single-market/

10. Fichman R.G. Going beyond the dominant paradigm for information technology innovation research: emerging concepts and methods. J Assoc Inf Syst, 2015. № 5(8), 314-325 p.

11. Карпенко О. Цифрова культура: соціальна сутність та комунікативні складові. Вісник Національної академії керівних кадрів культури і мистецтв, 2018. № 2. С. 51-54.

\section{References}

1. Roco M.C. (2003) Coherence and Divergence of Megatrends in Science and Engineering / Converging Technologies for Improving Human Performance NANOTECHNOLOGY, BIOTECHNOLOGY, INFORMATION TECHNOLOGY AND COGNITIVE SCIENCE. - NSF/DOC-sponsored report. Dordrecht: Kluwer Academic Publishers, 482. Retrieved from: https://www.wtec.org/ConvergingTechnologies/Report/NBIC_report.pdf [in English].

2. Toffler Alvin. (1995) Creating a New Civilization: The Politics of the Third Wave. Front Cover. /Alvin Toffler, Heidi Toffler/ Turner Pub. Business \& Economics [in English]. English].

3. Bell D. (1973) The Coming of Post-Industrial Society: A Venture in Social Forecasting. N.Y.: Basic books. [in

4. Masuda Y. (1994) The Information Society as Postindustrial Society. Wash.: World future soc. Wings to Human Ability / Government Commission on Information Technology. Sweden: Prime Minister's Office. [in English].

5. Drucker P. (1985) Innovation and Entrepreneurship, $=$ [in English]..

6. Porat M. (1978) The Information Economy: Development and Measurement. Wash. [in English].

7. Porter M. E., Kramer M. R. (2006) Strategy and Society: The Link Between Competitive Advantage and Corporate Social Responsibility // Harvard Business Review, December, 78-92 [in English].

8. About Improving connectivity and access. Retrieved from: https://ec.europa.eu/info/research-andinnovation_en [in English].

9. The European Commission. Official web-site. Retrieved from: https://ec.europa.eu/digital-single-market/

10. Fichman R.G. (2015) Going beyond the dominant paradigm for information technology innovation research: emerging concepts and methods. - J Assoc Inf Syst. № 5(8), 314-325. [in English].

11. Karpenko O. Digital culture: social essence and communicational constituents /O. Karpenko, V. Namestnik // Bulletin of the National Academy of Leaders of Culture and Arts, 2018. - No. 2 - P. 51-54. [in English].

Стаття надійшла до редакції 24.09.2018 p. 